\title{
Implementation of Accreditation-Based Management Standards at the Pontianak Green Community Learning Activity Center
}

\author{
Muhammad Rusli Abdillah ${ }^{1)}$, Wahyudi' ${ }^{2)}$, Sukmawati ${ }^{3)}$ \\ ${ }^{1)}$ Universitas Tanjungpura, Pontianak, Indonesia \\ E-mail: rusliabdillah301@gmail.com \\ ${ }^{2)}$ Universitas Tanjungpura, Pontianak, Indonesia \\ E-mail:wyudi_fkip@yahoo.com \\ ${ }^{3)}$ Universitas Tanjungpura, Pontianak, Indonesia \\ E-mail: sukmawati@fkip.untan.ac.id
}

\begin{abstract}
The purpose of this study is to describe the planning of accreditation-based management standards at the community learning center (PKBM) of Pondok Hijau in Pontianak and describe the planning of accreditation-based management standards at the learning center of Pondok Hijau Pontianak community. The approach used in this study is qualitative research, with ethnographic procedures, because researchers intend to explore in-depth and comprehensive information, then analyze, and interpret individual patterns or behaviors that develop over time in non-formal education units, namely PKBM. As for the object of research or data sources (informants) are: Chairperson, GTK, parents of students, figures / forums representative of the local community, Department of Education and Culture, as well as partners of education units that are used as research objects in PKBM Pondok Hijau Pontianak, and research results more emphasis on meaning than generalization. The results obtained from this study are 1) planning for the implementation of management standards has met the maximum achievement according to the PKBM unit accreditation assessment rubric; 2) implementation of management standards still need to be more intensively involved with related parties; 3) supervision of the implementation of management standards has not met the maximum achievement according to the accreditation guidelines; and 4) reports on the implementation of management standards meet the maximum achievements according to the rubric of accreditation assessment for PKBM clusters, both the results of activities and finances are reported in full per activity, submitted periodically to the relevant parties.
\end{abstract}

Keywords: Implementation; Management Standards; Accreditation

\section{INTRODUCTION}

Management of education units by national education standards (SNP) in the sense of resource structuring activities related to the application of management functions, is a demand that should be carried out, to maintain quality, relevance, efficiency and effectiveness of outputs and positive impacts (outcomes ) education services. About "Management Standards" according to the references of the Ministry of Education and Culture (Depdikbud RI) "is the national standard of education relating to the planning, implementation, and supervision of educational activities at the education unit level."

Management of service programs that refer to Government Regulation (PP) No. 19 of 2005 concerning SNP concerning the planning, implementation and supervision of educational activities at the education unit level, indicated by the availability of relevant documents, as physical evidence that can be used as reporting material, so that the service objectives can be categorized as effective and efficient in meeting the standards. In line with National Education System Law No. 20 of 2003 Article 60 paragraph (1) that the eligibility criteria for the provision of education services, both on formal and non-formal lines at every level and type of education, are education units that meet the criteria with accredited status.

Implementation of PKBM Management, as a formal education unit, must also refer to SNP, so that outputs and positive impacts (outcomes) are in line with education standards that apply throughout 
the jurisdiction of the Republic of Indonesia, following the criteria in Government Regulation No.19 of 2005 and PP No. 32 about the changes. Whereas, the scope of the 8 SNPs includes: (a) Content Standards, (b) Process Standards, (c) Graduates Competency Standards, (d) Standards of Educators and Education Personnel, (e) Standards of Facilities and Infrastructure, (f) Management Standards, (g) Financing Standards, and (h) Educational Assessment Standards. In this case, for the Management Standards (Standard six) is the standard that has the most status 'major' which must be fulfilled in the area of accreditation. In other words, for PKBM unit management to meet the criteria of at least 8 SNPs, the service work process inevitably - must - fulfill the accreditation demands of the National Accreditation Board for Early Childhood Education and Non-Formal Education (BAN PAUD and PNF) referring to the PKBM unit rubric. That includes fulfillment of implementation: (1) Leadership, (2) Work Plan, (3) Organizing, (4) Implementation of Management, (5) Supervision, (6) Reporting of Activity Results and Finance. Thus it can be interpreted that, PKBM units can be categorized as feasible to provide education services if they have been accredited.

Indicators of the fulfillment of the accreditation based PKBM unit self-evaluation document include 1. Implementation Plan Accreditation-based PKBM unit management: (a) must have a clear and realistic vision, (b) must have a clear and realistic mission, (c) must have clear and realistic objectives, (d) should have a guided village that is in accordance with the vision, mission, and objectives made, (e) should have a clear strategic plan (5 year work plan), (f) must have an operational work plan ( clear annual plan, (g) should have a funding plan for future activities, (h) should carry out Community Learning Needs Identification (IKBM) activities, (i) should use the IKBM results as a basis for determining the type of service program, ( $\mathrm{j}$ ) should include members/community leaders in each program preparation; 2. Implementation of Management Standards, including: (a) activity schedule, (b) list of students in each group, (c) continuous service program; 3. Supervision of Implementation of Management Standards, including (a) regular monitoring and evaluation (monev) of service programs, (b) making monev implementation reports, (c) having guidelines for implementing monev; 4. Reporting on the Implementation of Management Standards, including (a) making a complete report on the results of activities, (b) making a complete financial report, (c) making periodic financial and activity reports, (d) submitting results of activities and financial reports to all related parties.

In the notes of the West Kalimantan
Province Community Learning Center
Communication Forum (FK-PKBM West Kalimantan) as of November 2017, there are 246 PKBM that have National Education Unit (NPSN) Unit Numbers, connected online on the National Basic Education Data (Dapodik) system. , but no quarter has been accredited. The data is in line with the data on Profil Book Profile of Accreditation Results 'BAP PAUD and PNF West Kalimantan in 2017 that there are 246 total PKBM spread across 14 Regencies/Cities, the accredited PKBM cluster program reaches $21.54 \%$. About the program that has been accredited in the PKBM family in West Kalimantan, includes SD/MI equivalent Package A Program, SMP/MTs Package B equivalent, and Package C program equivalent to SMA / MA. The achievement of the average value of the accredited program, especially regarding the implementation of Management Standards, is still below $70 \%$. (Precisely only reached $67.50 \%$ ). The data includes program achievements in Non-Formal Education Unit Learning Activity Centers (SPNF-SKB) which are scattered in several districts/cities within the West Kalimantan region and are State-level education units in the Non-formal Education pathway. (By the nomenclature that has been determined by the central government that PKBM or SPNF-SKB units have not been accredited if their students will be included in the UNPK, they must refer to the nearest PKBM or SPNF-SKB district/city, whose service programs are accredited). Further information can be seen in the following picture:

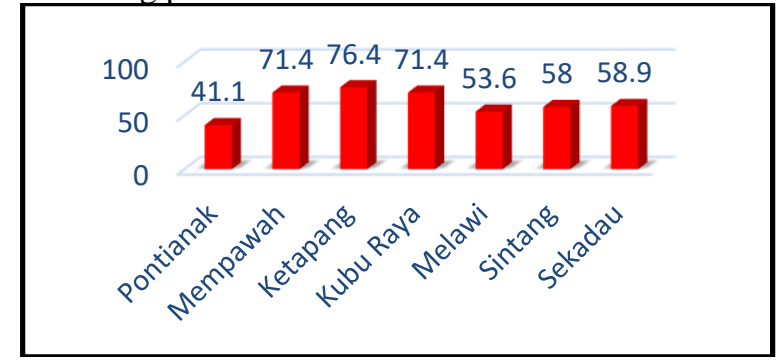

Fig. 1 Achievement of 8 SNP Accreditation Results in PKBM Kalbar Cluster

(Source: Book Profile of the Results of BAP PAUD \& PNF Accreditation Kalbar, 2017: 32)

In Figure 1 it is known that the location of accredited PKBM clusters that reach the maximum value is Ketapang Regency (76.4\%), while the lowest value is in PKBM-PKBM in Pontianak City (41.1\%). Regarding the achievement of the accreditation results of each standard on the 8 SNP of the PKBM program, we can see in the following picture: 


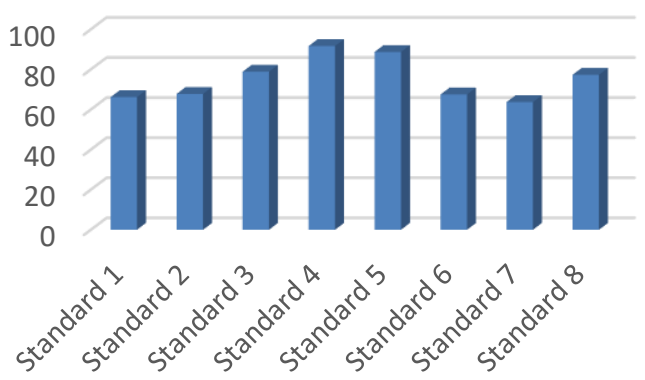

Fig. 2 Percentage of West Kalimantan Accredited PKBM Program Achievement Standards

The implementation of accreditation-based education management standards in the PKBM cluster education unit in West Kalimantan is still far from expectations, particularly the Implementation of Accreditation-Based Management Standards in PKBM (including SKB) in Pontianak City. In fact, ideally, PKBM management (and SKB) located in the provincial capital, should be used as a barometer or example in terms of service management, especially the achievement of a minimum service threshold according to SNP set by the government, fulfillment of management process requirements and supporting documents among others, marked by accreditation (as a condition to become a UNPK Organizer, both USBN and UNBK). On the other hand, Government Regulation Number 2 Year 2018 regarding Minimum Service Standards (SPM) is the provision of Basic Service Types and Quality which are the Mandatory Government Affairs that are entitled to be obtained by every citizen at a minimum, affirmed in Article 5 paragraph (3) that Basic Services Type in district/city education SPMs include: Early Childhood Education (PAUD) and Equality Education (Package A, B, and C Programs) organized by the Community Learning Center (PKBM) unit.

PKBM 'Pondok Hijau' Pontianak, which began operating in 2005, is one of 44 PKBM in Pontianak City that has NPSN, can be accessed online through the national Dapodik system connection, and one of the PKBM whose main service programs have been accredited. The Nonformal Pathways Education Unit, since 2015 received a Performance Assessment B. Starting in 2008, this PKBM opened several types of service programs in the former West Kalimantan Provincial Forestry Office building, known as the "Green Cottage" having its address at Jl. Khatulistiwa (Front of Teluk Mutiara) Siantan Village, North Pontianak District. PKBM is intended to carry out Life Skills, Community Reading Parks (TBM), Literacy Education, PUAD services (in 2016, accredited B), Equivalent Package A Equivalent to SD / MI Programs (in 2016, accredited A), Packages B is equivalent to SMP / M.Ts (in 2016, accredited B) and
Package C is equivalent to SMA/MA (in 2015, accredited $\mathrm{A}$ ).

The results of initial observations and interviews on the implementation of accreditationbased management standards in PKBM Pondok Hijau Pontianak, can be illustrated that, efforts to implement accreditation-based education management standards in terms of criteria for planning, implementation, and supervision (including reporting) of the results of service and financial services, have referred to SNP, indicated quite good, and seemed unique. Assessed refers to the SNP because almost all the main programs of its services have been accredited. Based on informal discussions with the PKBM chairman and treasurer, before determining the type of service program always begins with Community Learning Needs Identification (IKBM) first, and the IKBM results are used as a reference for the meeting, involving the participation of relevant education stakeholders. (The head of the local RT is given the authority as a field coordinator, especially in IKBM). It is said to be unique because the chairman leads all programs: Package A, B, and Package $\mathrm{C}$ at once. Other interesting things to observe in PKBM Pondok Hijau Pontianak include:

a. Free Literacy Education and Garden Education Service (TPQ) services,

b. Trusted as Organizer of National Standard School Examination (USBN) and ComputerBased National Examination (UNBK) Package A, B, and C programs).

c. Carry out service programs on an ongoing basis (not on-off), even though they are in a formal school environment (TK Kartika XVII-3) which first established and held similar service programs.

d. The land and building where the program is implemented are still borrowed (not their own), even though they have been operating since 2005.

e. Teaching practice place for female students from several universities in PAUD study programs.

f. Receiving many awards, both at Pontianak City Level, West Kalimantan Provincial Level, and National Level Awards and Achievements.

g. The researcher had conducted Visitation Accreditation (Site Visit) in PKBM in 2015, and as far as the researcher knew, no problem had been studied.

Based on the descriptions, data, and facts mentioned above, researchers researched the implementation of accreditation-based management standards relating to the planning, implementation, supervision, and reporting of service programs in the PKBM family. The study was entitled "Implementation of Accreditation-Based Management Standards at the Learning Center of Pondok Hijau Community in Pontianak." 


\section{RESEARCH METHOD}

The approach used in this study is qualitative research, with ethnographic procedures, because researchers intend to explore in-depth and comprehensive information, then analyze, and interpret individual patterns or behaviors that develop over time in non-formal education units, namely PKBM. In other words, the researcher as a key instrument intends to obtain objective, factual, accurate, and systematic data or images about the issues to be studied. As for the object of research or data sources (informants) are: Chairperson, GTK, parents of students, figures / forums representative of the local community, Department of Education and Culture, as well as partners of education units that are used as research objects in PKBM Pondok Hijau Pontianak, and research results more emphasis on meaning than generalization. Researchers try to do in-depth exploration of a limited system regarding time, place, or physical limits on the implementation of management standards in PKBM Pondok Hijau Pontianak

The type of research used in this case is a case study. Because, researchers try to do in-depth exploration by triangulating methods: interviews, observation (observing), and collecting documents to describe, analyze, and interpret group patterns related to the arrangement of integration of work activities applying management functions to PKBM as the subject of research, especially in the implementation of management standards from time to time. Also, this type of case study research seeks to develop an in-depth understanding of the implementation of educational management standards at PKBM Pondok Hijau Pontianak.

\section{A. Result}

\section{RESULT AND DISCUSSION}

In terms of the implementation plan of accreditation-based education management standards, starting from the determination of vision, mission, goals, village/auxiliary groups, strategic planning (5 years), operational plans (one year), future funding plans for service programs, are always discussed in meetings involving Educators, Education Personnel, and Community Representative Forums. Similarly, before determining the type of service program, it is always preceded by the Community Learning Needs Identification process (IKBM), and the results of the IKBM in the meeting are used as a basis for determining the type of program services. The meeting was chaired by the chairman; then the opportunity was opened to all who were present to participate in giving input, suggestions, opinions, which were recorded in the form of minutes of the meeting. If at the meeting the issues discussed have not been completed, the chairman makes the assignment of tasks according to their respective readiness and abilities as homework, to be matured again at the time of the next meeting. Among other things, those who take care of the borrowing and use permit of the place, and conduct Community Learning Needs Identification (IKBM) are delegated to the elements of the Community Representative Forum (which happens to be the head of the local RT, for the learning location in Gg. Mutiara Temple / but not valid for locations on J1 Kebangkitan Nasional and the development location in the village of Parit Massigi, Kabupaten Kubu Raya), the preparation of management documents per standard refers to 8 SNP delegated to the Teachers. The decision of the meeting was signed by the chairman and affixed with the institution's stamp.

In connection with the high enthusiasm of the surrounding community to put their children in PAUD, while the available capacity is limited, an effort is made to borrow government facilities that are no longer used due to streamlining of the relevant government agencies, some time ago. The implementation of the service program is sustainable, involving the participation of education stakeholders, conducting Community Learning Needs Identification (IKBM) according to the local context, the Head of the local RT as the field coordinator for data collection. In connection with the funding plan for activities held in the future to keep operating smoothly as needed, a business unit is opened. Between the time receiving a PAUD uniform order (every year the customer never breaks up); broiler maintenance on Jl. Trans Kalimantan, Parit Masigi, RT.02/RW.05, Kelurahan Ambawang Kuala, Kecamatan Sungai Ambawang, Kabupaten Kubu Raya, as well as opening the types of Raudhatul Athfal program services and the Paket A, B, and C programs, as the field coordinator is Azizah, S. Pd.I. The implementation of several types of service programs does not involve local community leaders in their implementation and supervision.

Also carried out regeneration efforts against (the forerunner of the establishment of a new education unit) in the development of types of service programs by the context and local potential, its implementation in several separate locations tailored to the needs of the local community. Among others, program services: (1) Literacy Education at Miftahussholihin Islamic Boarding School, Jl. National Awakening, Gg. Masjid, Kelurahan Siantan Hilir, (2) PAUD Rosela (Jl. Selat Sumba, Kelurahan Siantan Hulu, Kecamatan Pontianak Utara (Coordinator: Sulviawati), (3) PAUD Cahaya Khatulistiwa (J1. Khatulistiwa, Gg.1 Dalam, Batu Layang Village, North Pontianak Subdistrict), (4) PAUD Tunas Jaya, Purna Jaya Street, Purna Jaya I District, Siantan Hilir Village, North Pontianak Subdistrict, the assisted institutions which are nonformal education units, are now independent 
The impact of the accredited Paket A, B, C program has made the PKBM Pondok Hijau Pontianak every year trusted by the government to become the Organizer of the Equality Education National Examination (UNPK), and some PKBM that have (because they have not been accredited) and Salafi Islamic boarding schools are; (1) PKBM Hamka, (2) PKBM Pangeran Perbu, (3) PKBM AnNur, (4) Ponpes Al-Aziz (Jl. Parit Pangeran Gg. Metal, Siantan Hulu), (5) Ponpes Babussalam (Jl. Tani , East Pontianak). The MoU document attached on page 155 .

Supervision of the implementation of accreditation-based education management standards is carried out by the Chairperson of PKBM, but technically such as monitoring and evaluation delegated tasks are treasurer, some types of service programs do not involve local community leaders, conducting IKBM delegated to elements of the Community Representative Forum, preparing program service documents handled the teachers, Business Units are handled by the appointed coordinator based on the results of the decision of the meeting. Supporting documents can be seen on pages 152-160.

Periodic reporting of activity and financial results is presented to Community Representatives Forum, Pontianak City Education Office, and specifically from the central program is delivered per activity to the Director of Literacy Education and Equality Education Directorate General of Early Childhood Education and Community Education Ministry of Education and Culture, Jakarta. In general, report reports are made periodically by following the stages: initial report, implementation report (process) and final report, but some types of service programs are only made a final report and not reported to the local community representative forum.

\section{B. Discussion}

Based on the findings of the research results, about the discussion of the results of this study, directed to the study of findings about the implementation of accreditation-based education management standards that refer to the National Education Standards (SNP) relating to planning, implementation, supervision, and reporting at the Community Learning Learning Center (PKBM) Pontianak Green Cottage.

Planning for Accreditation-Based Management Standards Implementation

Planning Implementation of AccreditationBased Management Standards at the Learning Activity Center Pontianak Pondok Hijau Community includes availability: vision, mission, goals, strategic plan (5 years) and operation plan (1 year), future program funding plans by developing business units, networking partnerships and submitting proposal to related agencies, as well as community involvement in the preparation of service programs. .

Planning is an activity to prepare work activities through the formulation and determination of decisions in the form of problem-solving steps, so that the objectives of the education service program are carried out effectively, efficiently, and on time according to the objectives designed by the institution that is accreditation-based. In line with Dror, in Jones \& Walters (2008: 70) that "planning as a process of preparing a series of decisions for future actions in achieving the main objectives." Whereas what is meant by planning, in this case, is the preparation of structuring the implementation of management standards referring to the fulfillment of 8 SNPs, towards accredited types of service programs. Thus, planning management standards in this study can be interpreted as preparation for the process of making educational service targets in the future, to be able to ensure some Teachers and Education Personnel (GTK) in PKBM Pondok Hijau Pontianak are involved together to meet the minimum criteria for the implementation of management standards. Education services by the education system that applies throughout the territory of the Republic of Indonesia. According to Syaiful Sagala (2013: 141), the planning process is carried out collaboratively or collaboratively, meaning that it involves school personnel in all stages of planning. This partnership will create a sense of belonging that can encourage teachers and other school personnel to try to make the plan work. In the PKBM clump accreditation assessment rubric, it is stated that the PKBM unit management plan is ideal, the indicators are: (a) must have a clear and realistic vision, mission, and objectives, (b) should have a village / target group that is in accordance with the vision, mission and objectives made, (c) should have a strategic plan (5 years), must have a clear operational plan (one year), and should have a funding plan for future activities, (d) should carry out Community Learning Needs Identification (IKBM) activities and using the results of the IKBM as a basis for determining the type of service program, (e) should include members/community leaders in each program preparation.

Based on the results of interviews and documentation studies it can be concluded that planning the implementation of management standards in PKBM Pondok Hijau Pontianak, the first step is to formulate the vision, mission and objectives of the institution in a manner, prepared by the chairman, discussed at member meetings, involving GTK and community representative forums, through consensus deliberation, set as a joint decision to be carried out jointly (collegial collective). Likewise, regarding the determination of villages/target groups, strategic plans (5 years), operational plans (one year), future funding plans regarding service programs. 
Furthermore, each will determine the type of service, first conduct Community Learning Needs Identification (IKBM) or needs assessment, involving the Chairperson of RT as the representative of the local community representatives/forum as the field coordinator. With the implementation of IKBM or needs assessment and the Chairperson of the local RT as the executor, it is in line with the opinion of Suharsimi Arikunto \& Cepi Sarifudin (2014: 71) which states that "needs analysis is a process carried out by someone to identify needs while determining priorities in it." Simultaneously by the view of Wina Sanjaya (2016: 57) that "schools that have good relationships with outside institutions will increase the smoothness of school programs so that school efforts to improve the quality of learning will receive support from outsiders." The IKBM results are used as a basis for determining the type of service program taken through the meeting decision process involving the participation of Teachers and Education Personnel as well as community leaders / elements of the community representatives forum, meeting the demands of the National Education System Law No. 20 of 2003 article 8 which mandates that the community has the right to participate in the planning ... education program. The involvement of other parties (internal and external), according to Wina Sanjaya (2016: 57) fosters a positive climate for the social-psychiatric environment. The socialpsychological climate internally is the relationship between people involved in the environment of the education unit (school): among students, educators, education personnel, and leaders of education units. As for the external social-psychological climate is the harmony of the relationship between the education unit (school) and the outside world, for example, school relations with parents of students, school relations with community institutions, etc. The meeting is led directly by the PKBM chairman, the planning discussion is arranged based on input, proposal, and suggestion from the meeting participants, followed up with the division of tasks to prepare management standard documents whose criteria refer to the National Education Standards (SNP), the results of the deliberation decisions recorded by the minutes of the meeting were signed by the chairman and stamped with the institution. matching the views of Veitzal Ravai \& Sylvia Murni (2010: 168) "the essence of school-community relations is to increase involvement, initiation, and support from the community, especially moral and financial support." The task of internal monitoring and evaluation (monev) is delegated by the PKBM Chair to Wind (Azizah, S. Pd.I) assisted by the coordinator of each program organizer. By the opinion of Paul Hersey, in Nurhattati Fuad (2014: 211) that "delegation of authority (authority, authority) is an attempt to empower others through individual assignments by transferring the tasks of people who help the achievement of the organization."

The planning workflow carried out in PKBM Pondok Hijau Pontianak mentioned above, according to Hamzah B. Uno by the implementation of participatory management (2014: 93) namely "involving the participation of the community so that all policies and decisions taken are joint policies and decisions, to achieve joint success." The views of Donni Juni Priansa and Rismi Somad (2014: 39) that in the management of education units are strongly recommended to involve the community and other partnership networks. He added, "The elements of society that can be invited to work with schools include parents of students, institutions in the community, community leaders, religious institutions, community organizations, local government, donors, and entrepreneurs, as well as the industrial world."

This is also in accordance with the new paradigm of education center according to Anne Wescott \& Jean L. Konzal, in Donni and Rismi (2014: 10) that the responsibility of managing education is not enough to be left to educators (teachers), principals, and administrative staff in school only, but should involve the role of synergistically all education stakeholders. By the National Education System Law No. 20 of 2003 article 35 paragraph (2) that as a reference for management is the National Education Standards.

Also found at the time of document study (in the minutes of participants' attendance and attendance list, 5-year strategic plan, and one-year operational plan), and an annual program review schedule. According to Veithzal Rivai and Sylvina Murni (2010: 124) that the strategic plan is a reference and guideline for all levels of education providers, both central and regional governments, in planning and implementing national development processes in the field of education in the next five years. The drafting of the strategic plan is carried out transparently by involving various parties, both from the government, the business world, the education world, NGOs, and experts, both at the central and regional levels.

The connection with the review or evaluation of the program, the opinion of Mohammad Faisal Amir (2015: 58) that "program evaluation is the activity of gathering information carefully about a program or a particular part in the program for making organizational or company decisions."

So it can be concluded that PKBM Pondok Hijau Pontianak has a clear vision, mission, and objectives, the village/target group that is in accordance with the planned vision, mission, and objectives, has a reference plan for the activities carried forward, carrying out Community Learning Needs Identification ( IKBM) and make the IKBM as the basis for determining the type of service program, 
have a funding plan for sustainable development of services in the future, an effort to empower other parties internally by delegating tasks to the Treasurer and coordinator of program providers in monev rights, and involving educators, education staff and forums for community representation in each formulation of service programs

Also, PKBM Pondok Hijau Pontianak has guidelines governing: curriculum and syllabus, education calendars for all categories of activities for one year, and is detailed semi-annually, monthly, even weekly/daily (for PAUD), as well as organizational structure and division of tasks ( job description) GTK. This is in accordance with PP No. 19 of 2005 concerning SNP and PP No. 32 of 2013 concerning the amendment, article 52 paragraph (1) that each education unit must have guidelines governing (a) curriculum and syllabus, (b) education calendar, (c) organizational structure, (d) division of duties of teachers and education personnel (GTK). In the five-year strategic plan for Pontianak, Green Poncho PKBM stated that there are education and training programs to improve the skills and knowledge of educators and education personnel. Which according to Syaiful Sagala (2011: 179) "considering the importance of the role of education personnel in schools, school management must have education and training programs to improve the quality of school work." Thus, the researchers conclude that the planning of the implementation of management standards carried out in PKBM Pondok Hijau Pontianak fulfills the maximum achievements, by the guidelines contained in the accreditation section of PKBM clumps. (Documents can be viewed on pages 137 and 203).

Implementation of Accreditation-Based Management Standards

Implementation of Accreditation-Based Management Standards at the Pontianak Green Pond Community Learning Center by conducting Community Learning Needs Identification (IKBM), the results are discussed at the meeting and used as the main basis for determining the type of service program, completing the activity schedule data, and attendance lists of students, as well as towards a continuous learning process.

The implementation of education services is an activity process to ensure that the designed goals can be implemented according to the plan outlined on schedule, have a list of students for each type of service program, the service program can be carried out on an ongoing basis, no one breaks every year. There are several theories about the implementation strategy of a service program so that it can take place continuously, namely by involving the participation of partners/community.

Mulyasa asserted, (2016: 137) that

"... community participation is indispensable, and the community must be a school partner in carrying out education and learning because cooperation between the two is very important in shaping students' personalities". According to Hamzah B. Uno (2014: 93) "In addition to implementing the curriculum that has been established from the center, province, and district/city, schools can also develop life skills education programs that are appropriate to the circumstances and needs of the surrounding community."

Based on the results of interviews and documentation studies, it can be concluded that PKBM Pondok Hijau Pontianak has implemented service programs in accordance with applicable procedures, there are activity schedules for each activity (both structured and unstructured activities), and has a list of students for each type service programs: PAUD, Equality, Literacy, and life skills participants, and all types of service programs run continuously, always there every year. Especially for the Equality Education program, 2017 was not implemented because students (learning citizens) the level of Basic Literacy has been completed, the government only offers an advanced service program in the form of Keksaraan Usaha Mandiri (KUM). The KUM program can only be accessed by learning citizens who have completed the learning process of Basic Literacy, as evidenced by attaching photographs of Literacy Literacy (SUKMA). While the learning citizens (students) of Pondok Hijau PKBM have completed the Basic Literacy 2016, but due to delays in obtaining SUKMA (which the certificate is issued by the Ministry of Education and Culture) cannot access the KUM program in 2017.

Carry out regeneration in the sense of helping managerial non-formal education units so that they can manage education service programs independently. These institutions are already independent, namely: (1) early childhood Roselle, (2) ECD Tunas Jaya, (3) ECD Light Equator (now renamed Salsabila ECD), (4) PKBM Miftahussolikhin.

Some educational units have its to CLC Pondok Hijau Pontianak in UNPK system UNBK, namely: (1) PKBM Hamka, (2) PKBM An-Nur, (3) PKBM Prince Perbu, (4) Pesantren Al-Aziz, (5) Ponpes Babussalam. Where, in the education service process, according to H.A.R. Tilaar (2004: 23) that "The community assists the organization and controls its implementation, while the activities within the educational institution are carried out by authorized and professional personnel." According to Jones \& Walters (2008: 33) "one of the other needs in human resource management in schools is increasing the participation of teaching staff." Furthermore, according to Tilaar, et al. (2004: 58) "Community participation in the implementation of education also means empowering the community itself in participating in determining the direction and 
contents of its education." According to St. Rodliyah (2013: 33) that "public participation is community participation in planning, executing, controlling, and evaluating and was able to increase the receptivity and ability to respond, either directly or indirectly, since of ideas, formulation of policies and the implementation of the program."

Regarding implementing the implementation of management standards, PKBM Pondok Hijau Pontianak still needs more involving the participation of the surrounding community in particular, both direct and indirect involvement. So it can be concluded that regarding the implementation of management standards it still does not meet the maximum standards of the PKBM unit clusters accreditation rubric.

Supervision of Management Standards Based on Accreditation

Supervision of Accreditation-Based Management Implementation at the Pondok Hijau Community Learning Activity Center in Pontianak in the form of monitoring and evaluation (monev) and reporting delegated by the head of the institution to the respective service program coordinators, using formal school monev guidance.

Controlling in accreditation-based education services is a process of action checking the governance of the implementation of planning objectives, designing a feedback information system, comparing real activities with predetermined standards, determining and measuring deviations, and taking corrective actions. All educational resources run most effectively and efficiently referring to eight national education standards.

There are several supervision strategies carried out by managers at PKBM Pondok Hijau Pontianak. The main way is to monitor and evaluate (monev) the delegation of tasks given by the chairman to the field coordinator or appointed officer. Based on the results of the interview with the Chairperson of the RT where the Literacy Education program was held, the Head of the RT was involved in the initial phase, namely conducting IKBM, but felt that he was not involved in the service program evaluation meeting. According to H.A.R. Tilaar (2004: 22) that "Education rooted in society also means the participation and control of the community that owns the education." According to Nurhattati Fuad (2014: 84), community-based education emphasizes community engagement in planning, implementing, and evaluating learning effectiveness and utilization of outcomes, and utilizing the involvement of various constituents of the community (multiple constituents involvement). View of Cohen and Uphoff, in Siti Irene (2015: 61) there are four types of participation, namely, first, participation in making decisions; second, participation in implementation; third, participation in taking benefits; fourth, participation in evaluation.
Guidelines for implementing monev are not found. Because there is not enough evidence to illustrate that there is involvement of the community in terms of monitoring service programs, it can be concluded that PKBM Pondok Hijau Pontianak in terms of monitoring the implementation of management standards including not meeting the maximum achievement of accreditation demands, the involvement of local community leaders in evaluating and utilizing learning outcomes of each type of service program, the involvement of various elements of the community concerned, as well as providing guidance on the implementation of Monev in accordance with the 8 National Education Standards.

Reporting on Management Standards Based on Accreditation

Report on the Implementation of Accreditation-Based Management Standards at the Learning Activity Center of the Pondok Hijau Community in Pontianak, both activity, and financial reports are made every time the service program is completed; it is carried out periodically to all relevant parties.

Reporting is made in the form of a process to "guarantee" that the goals of education services are achieved according to planning at each stage of work, as well as useful to know the implementation, development, obstacles, and success of education service programs that have been carried out referring to 8 SNPs. According to Stufflebeam \& Coryn (2014: 15) "Effective reporting sets the stage for applying the evaluation findings" - effective reports can be used regarding the need for assessment findings. There is monitoring report according to the reference of the Directorate of Community Education Development (2012: 1) to ensure the quality of the results and the smooth process of the activities. The monitoring objectives include: (1) The implementation of activities supported by physical evidence according to the steps of the activities that have been determined; (2) Constraints to the implementation of activities related to qualitative objectives and the time set; (3) Finding solutions to problems experienced. In the scoring guide rubric in the PKBM cluster accreditation process, it is stated that the indicators of implementing an ideal management standard for an institution include: (a) making a complete report on activities, (b) making a complete financial report, (c) making activity and financial results reports periodic, (d) submit reports on activities and financial results to all parties concerned.

Regarding reporting the implementation of management standards, PKBM Pondok Hijau Pontianak has implemented it by the applicable procedures and mechanisms, namely making a report after completing the service program and reporting its financial use at once. Both activity reports and 
financial reports are made according to the specified period (initial report, mid-report, and final report). The activity and financial reports are submitted to the relevant parties, well documented and complete, delivered on time. It can be concluded that the reporting of the implementation of management standards in PKBM Pondok Hijau Pontianak, fulfills the maximum achievement of the demands of the PKBM unit cluster accreditation rubric.

\section{CONCLUSIONS AND SUGGESTIONS}

\section{A. Conclusions}

Based on the results of the research and discussion on the implementation of accreditation-based management standards related to planning, implementation, supervision, and reporting referring to 8 SNPs at the Pondok Hijau Community Learning Activity Center (PKBM) Pontianak, the following conclusions can be drawn:

1. Planning the implementation of management standards, has fulfilled the maximum achievements, according to the rubric of the accreditation assessment of PKBM unit clusters, namely having: clear and realistic vision, mission, and objectives; target groups according to the vision, mission and goals of the institution; 5-year strategic plans and oneyear operational plans are available, future funding plans are developed in partnership with various parties; implement IKBM and the results are used as the basis for determining the types of service programs.

2. Implementation of the management standard still needs to be more intensively involved with related parties. Has: activity schedule for each activity, list of students for each study group in each type of service program, continuous service program so that there is no free time in each year. It's just that there is still a lack of involvement of the local community to contribute to the implementation phase of the service program.

3. Supervision of implementation of management standards has not met the maximum achievement according to the accreditation guidelines, indicated: the manager carries out monitoring and evaluation (monev) of the service program periodically, but not with interview techniques with educators and students, as well as no evidence of written data; have an internal monev implementation report for the program every semester, but not routine; have guidelines for implementing monev adopting from formal schools; lack of involvement of the wider community in monitoring the implementation of types of literacy education service programs.
4. The report on the implementation of management standards meets the maximum achievement according to the rubric of the accreditation assessment of PKBM clusters, both the results of activities and finances are reported in full per activity, submitted periodically to the relevant parties.

B. Suggestions

It is recommended/recommended that:

1. Parties related to the implementation of accreditation-based education management in PKBM units, in particular, to open opportunities for community involvement at all stages: planning, implementation, supervision, and evaluation, in each type of service program.

2. There are researchers who conduct further research related to the implementation of accreditation-based management standards on the variables of Leadership, Organizing, and Evaluation.

\section{REFERENCES}

Arikunto, Suharsimi dan Abdul Jabar, Cepi Safrudin. 2004. Evaluasi Program Pendidikan, Pedoman Teoritis bagi Praktisi Pendidikan. Bumi Aksara: Jakarta.

Astuti, Irene Siti. 2015. Desentralisasi dan Partisipasi Masyarakat dalam Pendidikan. Yogyakarta: Pustaka PelajarFaisal Amir, Mohammad. 2015. Memahami Evaluasi Kinerja Karyawan. Jakarta: Mitra Wacana Media.

BAP PAUD \& PNF. 2017. Profil Hasil Akrditasi PAUD \& PNF Kalimantan Barat Tahun 2017. Pontianak: BAP PAUD \& PNF Kalbar.

Fuad, N. 2014. Manajemen Pendidikan Berbasis Masyarakat - Konsesp dan Strategi Implementasi. Jakarta: Raja Grafindo Persada.

Jones, J. James \& Walters, L. Donald. 2008. Human Resource Management in Education Manajemen Sumber Daya Manusia dalam Pendidikan. Sleman Yogyakarta: Q-Media.

Mulyasa, E. 2016. Guru Dalam Implementasi Kurikulum 2013. Bandung: Remaja Rosdakarya.

Peraturan Pemerintah No. 32 Tahun 2013 tentang perubahan Peraturan Pemerintah No. 19 Tahun 2005 Tentang Standar Nasional Pendidikan.

Priansa, D \& Somad, R. 2014. Manajemen Supervisi dan Kepemimpinan Kepala Sekolah. Bandung: Alfabeta.

Rivai, V. \& Murni, S. 2010. Education Management - Analisis Teori dan Praktek. Jakarta: PT. RajaGrafindo Persada. 
Rodliyah, S. 2013 Partisipasi Masyarakat dalam Pengambilan Keputusan dan Perencanaan di Sekolah.

Sagala, S. 2013. Konsep dan Makna Pembelajaran. Bandung: Alfabeta.

2011. Manajemen Strategik Dalam Peningkatan Mutu Pendidikan. Bandung: Alfabeta.

Sanjaya, W. 2016. Strategi Pembelajaran Berorientasi Standar Proses Pendidikan. Jakarta: Kharisma Putra Utama.

Stufflebeam, Coryn. 2014. Evaluation Theory Models, \& Applications-Second Edition. San Francisco: Jossey - Bass.

Tilaar, H. 2004. Manajemen Pendidikan NasionalKajian Pendidikan Masa Depan. Bandung: Remaja Rosdakarya.

2004. Paradigma Baru Pendidikan

Nasional. Jakarta: Rineka Cipta.

Uno, Hamzah, B. 2014. Profesi Kependidikan Problema, Solusi, dan Reformasi Pendidikan di Indonesia. Jakarta: Bumi Aksara.

Undang Undang Sisdiknas No. 20 Tahun 2003. Pasal 26 ayat (4) Satuan Pendidikan Nonformal terdiri atas lembaga kursus, lembaga pelatihan, kelompok belajar, PKBM, dan majlis taklim, serta satuan pendidikan yang sejenis. 